\title{
BMJ Open Association between renal function and cardiovascular mortality: a retrospective cohort study of elderly from health check-up
}

\author{
Ying-Jhen Huang, ${ }^{1}$ Yu-Lin Hsu, ${ }^{1}$ Yung-Hsin Chuang (D) , ${ }^{1,2}$ Hugo Y -H Lin,,${ }^{3,4,5}$ \\ Yen-Hsu Chen, ${ }^{6,7,8,9}$ Ta-Chien Chan (iD 1,2
}

To cite: Huang Y-J, Hsu YL, Chuang Y-H, et al. Association between renal function and cardiovascular mortality: a retrospective cohort study of elderly from health check-up. BMJ Open 2021;11:e049307. doi:10.1136/ bmjopen-2021-049307

- Prepublication history and additional supplemental material for this paper are available online. To view these files, please visit the journal online (http://dx.doi.org/10.1136/ bmjopen-2021-049307)

Received 22 January 2021 Accepted 02 September 2021

Check for updates

(C) Author(s) (or their employer(s)) 2021. Re-use permitted under CC BY-NC. No commercial re-use. See rights and permissions. Published by BMJ.

For numbered affiliations see end of article.

Correspondence to

Dr Ta-Chien Chan;

dachianpig@gmail.com

\section{ABSTRACT}

Objectives This study aimed to investigate the relationship between cardiovascular mortality in elderly Asians and decline in renal function.

Design A retrospective cohort study.

Setting Community-based health examination database from Taipei city.

Participants At the beginning, the database included 315045 health check-up visits of 97803 elderly persons aged $\geq 65$ years old from 2005 to 2012 . After excluding missing values and outliers, there were 64732 elderly persons with at least two visits retained for further analyses.

Primary outcome measures Kidney function indicators include estimated glomerular filtration rate (eGFR) and urine protein, and rapid decline in eGFR was defined as slope $\leq-5 \mathrm{~mL} / \mathrm{min} / 1.73 \mathrm{~m}^{2}$ per year. The endpoint outcome was defined as the cardiovascular deaths registered in the death registry encoded by the International Classification of Diseases. We applied a Cox proportional hazards model to analyse the association between renal function and cardiovascular mortality. Results In this study, we found 1264 elderly persons died from cardiovascular diseases, for whom the data included 4055 previous health check-up visits. We observed significant and independent associations of eGFR $<60 \mathrm{~mL} /$ $\mathrm{min} / 1.73 \mathrm{~m}^{2}$ (HR $(95 \% \mathrm{Cl})$ of $60>$ eGFR $\geq 45$ and eGFR $<45$ in males: 2.85 (1.33 to 6.09) and 3.98 (1.84 to 8.61); in females: 3.66 (1.32 to 10.15) and 6.77 (2.41 to 18.99)), positive proteinuria $(\mathrm{HR}(95 \% \mathrm{Cl})$ of $+/-,+,++$ and +++ , ++++ in males: 1.51 (1.29 to 1.78) and 2.31 (1.51 to 3.53); in females: 1.93 (1.54 to 2.42) and 4.23 (2.34 to $7.65))$ and rapid decline in eGFR $(\mathrm{HR}(95 \% \mathrm{Cl})$ in males: 3.24 (2.73 to 3.85); in females: 2.83 (2.20 to 3.64) with higher risk of cardiovascular mortality. The joint effect of increased concentration of urine protein and reduced eGFR was associated with a higher risk of cardiovascular mortality.

Conclusions Renal function and rapid decline in renal function are independent risk factors for cardiovascular mortality in the elderly.

\section{INTRODUCTION}

Chronic kidney disease (CKD) is a common disease among the elderly, and is defined
Strengths and limitations of this study

- A cohort study in a large and representative elderly population in Taiwan's capital.

- Fills gaps in the relevant research on elderly Asians and considers the effect of gender.

- Our findings could provide an early warning to identify groups with a high risk of cardiovascular mortality.

- The proteinuria test uses urine test strips instead of the albumin-to-creatinine ratio.

- The results cannot extrapolate to the entire Asian elderly population.

as structural or functional abnormality of the kidney (glomerular filtration rate (GFR) $<60 \mathrm{~mL} / \mathrm{min} / 1.73 \mathrm{~m}^{2}$, albuminuria or markers of kidney damage) for 3 months or more in clinical diagnosis. ${ }^{1}$ With ageing, the structure and physiology of the kidneys change, leading to decline in the functions of waste removal, maintenance of electrolyte balance and regulation of blood pressure. Hypertension, diabetes, long-term inflammation and urological diseases (such as prostate hypertrophy and urinary tract stones) are not only common chronic diseases in the elderly, but also common causes of deterioration of renal function, and contribute to CKD progression. ${ }^{2} 3$ In addition, the elderly are a population at high risk for acute kidney injury because of physiological age-related changes or polypharmacy and drug toxicity, ${ }^{24}$ and probably develop CKD in the context of incomplete repair of renal tubular epithelial cells, glomerulosclerosis, ischaemiareperfusion injury and fibrosis. ${ }^{56}$

Cardiovascular disease (CVD) is the leading cause of death worldwide, causing an estimated 17.8 million deaths in $2017 ;^{7}$ approximately 1.4 million out of all CVD deaths are attributable to impaired renal function. ${ }^{8}$ 
Clarifying the relationship between renal function and cardiovascular mortality is vital, so as to enable early intervention to reduce the social and medical burden. Many studies have found evidence that CKD is an independent risk factor for CVDs and cardiovascular mortality and have suggested possible mechanisms for this. ${ }^{9-11} \mathrm{~A}$ joint effect of estimated GFR (eGFR) and proteinuria on the adverse outcomes has been proposed, and it is suggested that combining the two indicators of renal function provides a better estimation for the risk of cardiovascular mortality, ${ }^{12-14}$ especially in the elderly over $70 .{ }^{12}$ However, there are still studies which do not support this hypothesis. Wang et al reported no significant association of the joint effect of eGFR and urinary albumin-to-creatinine ratio (ACR) with either all-cause or cardiovascular mortality among participants, non-institutionalised adults (18 years or older), of the China National Survey of CKD in China. ${ }^{15}$ In addition to affecting the prognosis of renal function, ${ }^{16-18}$ the magnitude of renal function decline (eGFR slope) is also related to the increased risk of cardiovascular events ${ }^{1920}$ and cardiovascular mortality. ${ }^{2122}$ However, to the best of our knowledge, such epidemiological studies are limited and have not yet included Asian elderly populations.

The objective of this study was to clarify the independent relationship between the risk of CVD mortality among the elderly in Taiwan and their renal function and its decline. More specifically, the present study aimed to determine whether the eGFR, proteinuria and eGFR slope are independent risk factors of cardiovascular mortality, and examine the joint effect of eGFR and urine protein to propose a combination more suitable for predicting the cardiovascular mortality risk of the elderly in Taiwan.

\section{METHOD}

\section{Study design and ethical statement}

This research was designed as a retrospective longitudinal cohort study based on an elderly health examination database. Participants were enrolled, with informed consent signed and submitted to Taipei City Government, to record health examination data for research purposes. This database is linked to Taiwan's National Death Registry from 2005 to 2012 by using the participants' identification number and personal information encrypted by the data managers. Data were stored in the Taipei Geriatric Health Examination Database, and labels were deidentified before release.

\section{Patient and public involvement}

This study obtained secondhand data; participants did not receive feedback on the results and were not involved in the study.

\section{Cohort description}

This community-based cohort study used data from the Taipei City Elderly Health Examination Database. The study period covered 2005-2012. The Taipei City

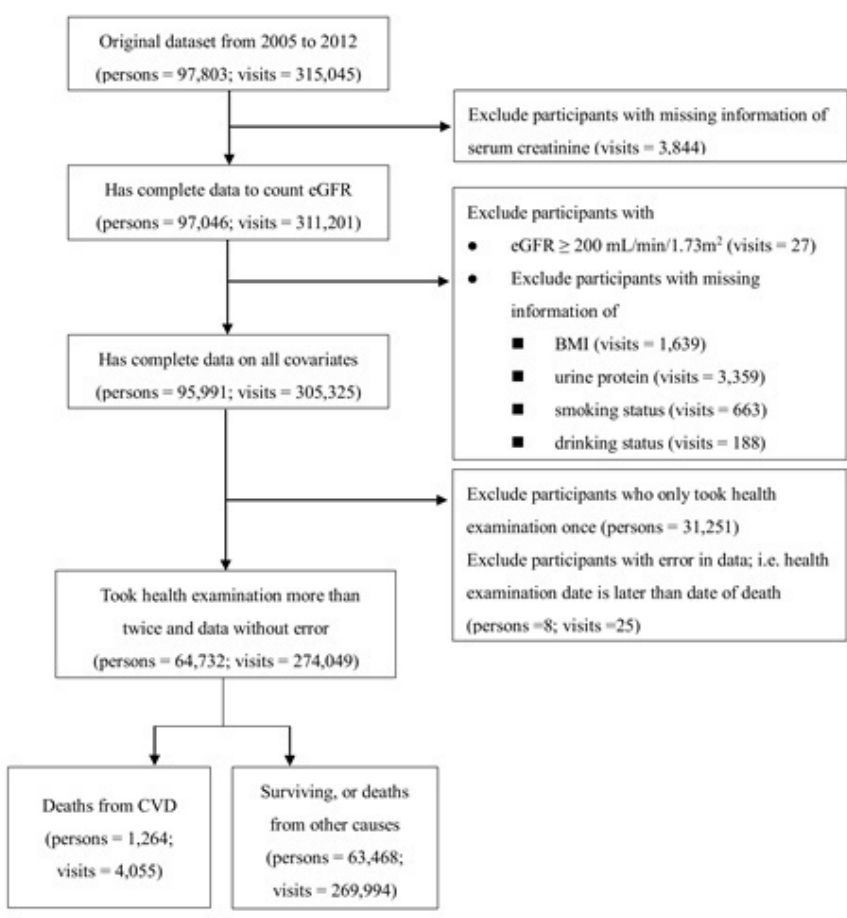

Figure 1 Flow chart for selection of participants. BMI, body mass index; CVD, cardiovascular disease; eGFR, estimated glomerular filtration rate.

Government provides free annual elderly health examinations in Taipei City. On average, around 42000 elderly persons each year participate in the examinations, which accounts for $13 \%$ of the registered elderly population in Taipei City. All participants received a health examination once annually.

\section{Selection of participants}

At the beginning, the database included 315045 health check-up visits of 97803 elderly persons aged $\geq 65$ years old from 2005 to 2012. The selection process is shown in figure 1 . The renal function assessed by the estimated GFR (eGFR) is one of our important explanatory variables. We used the Berlin Initiative Research calculation formula, which is more suitable for evaluating the glomerular filtration in the elderly. The formula is eGFR (mL/ $\left.\min / 1.73 \mathrm{~m}^{2}\right)=3736 \times$ serum creatinine $-0.87 \times($ age $)-0.95$ $\times(0.82$ if female $) .{ }^{23}$ Thus, we excluded data for visits without a serum creatinine test (visits=3844). Additionally, we excluded participants with abnormal eGFR $(\geq 200 \mathrm{~mL} /$ $\left.\min / 1.73 \mathrm{~m}^{2}\right)$ (visits=27) and those with missing values for explanatory variables, including body mass index (BMI) (visits=1639), urine protein (visits=3359), smoking status (visits $=663$ ) and drinking status (visits=188). Furthermore, we excluded participants who had taken the health examination only once (persons $=31251$ ) and those with erroneous data (with a date of death preceding the health check-up) (persons=8; visits=25). Finally, 64732 elderly persons and 274049 visits were retained for further analyses. The endpoint outcome was defined as the cardiovascular deaths registered in the death registry encoded by the ninth or tenth revision (with death year 
after 2009) of the International Classification of Diseases (ICD-9 or ICD-10). The ICD-9 codes are defined from 390 to 459 , and the ICD-10 codes are defined in Chapter 9 (cardiovascular system) of ICD-10 (https://icd.who.int/ browse10/2008/en\#/IX). In this study, we found 1264 elderly persons died from CVDs (4055 visits), 4002 died from non-CVD (13014 visits) and 59466 lived until the study end (256980 visits).

\section{Definition of explanatory variables}

There are 10 explanatory variables used in the statistical analyses: (1) Age group: We coded participants aged older than 75 years old as 1 , and those $65-74$ years old as 0, (2) BMI: We classified BMI into six groups based on the suggestion from the Health Promotion Administration, Ministry of Health and Welfare, Taiwan (https:// health99.hpa.gov.tw/OnlinkHealth/Onlink_BMI. aspx). We treated normal weight $\left(18.5 \mathrm{~kg} / \mathrm{m}^{2} \leq \mathrm{BMI}<\right.$ $\left.24 \mathrm{~kg} / \mathrm{m}^{2}\right)$ as the reference group. The remaining five groups are underweight (BMI $<18.5 \mathrm{~kg} / \mathrm{m}^{2}$ ), overweight $\left(24 \leq \mathrm{BMI}<27 \mathrm{~kg} / \mathrm{m}^{2}\right)$, slightly obese $(27 \leq \mathrm{BMI}<30 \mathrm{~kg} /$ $\left.\mathrm{m}^{2}\right)$, moderately obese $\left(30 \leq \mathrm{BMI}<35 \mathrm{~kg} / \mathrm{m}^{2}\right)$, and severely obese (BMI $\geq 35 \mathrm{~kg} / \mathrm{m}^{2}$ ), (3) History of heart disease: participants who fulfilled one of three criteria, including medical history of heart disease, regularly taking medicine because of heart disease or reporting having heart disease, (4) History of hypertension: participants who fulfilled one of four criteria including high blood pressure (systolic pressure $\geq 140 \mathrm{~mm} \mathrm{Hg}$ or diastolic blood pressure $\geq 90 \mathrm{~mm} \mathrm{Hg}$ ), a history of hypertension, regularly taking medicine because of hypertension, or reporting having hypertension, (5) History of diabetes: participants who fulfilled one of four criteria including high fasting glucose $(\geq 126 \mathrm{mg} / \mathrm{dL})$, a history of diabetes, regularly taking medicine because of diabetes, or reporting having diabetes, (6) Smoking status: We classified smoking status into three groups, including non-smoking (as a reference), smoking occasionally and smoking every day, (7) Drinking status: We classified drinking status into two groups, including non-drinking (as a reference) and drinking, (8) eGFR class: We classified eGFR into four groups, including eGFR $\geq 90 \mathrm{~mL} / \mathrm{min} / 1.73 \mathrm{~m}^{2}$ (as a reference), $60 \mathrm{~mL} / \mathrm{min} / 1.73 \mathrm{~m}^{2} \leq \mathrm{eGFR}<90 \mathrm{~mL} / \mathrm{min} / 1.73 \mathrm{~m}^{2}$, $45 \mathrm{~mL} / \mathrm{min} / 1.73 \mathrm{~m}^{2} \leq \mathrm{eGFR}<60 \mathrm{~mL} / \mathrm{min} / 1.73 \mathrm{~m}^{2}$, and eGFR $<45 \mathrm{~mL} / \mathrm{min} / 1.73 \mathrm{~m}^{2}$, (9) eGFR Decline: We defined this as the mean rate of change in eGFR from first (baseline) to last visit in the follow-up for each participant [eGFR slope $=3736 \times$ serum creatinine $-0.87 \times($ age $)-0.95 \times$ (0.82 if female)/years]. Then, eGFR decline was classified into two groups, including slope $>-5 \mathrm{~mL} / \mathrm{min} / 1.73 \mathrm{~m}^{2} /$ year (as a reference) and slope $\leq-5 \mathrm{~mL} / \mathrm{min} / 1.73 \mathrm{~m}^{2} /$ year and (10) Urine protein: We classified this into three groups, including - (as a reference),$(+/-,+,++)$ and $(+++$ or ++++$)$.

\section{Statistical analyses}

All analyses were performed with RStudio software V.1.2.5033 (2009-2019 RStudio). In the survival analysis, to evaluate the effects of multiple variables on cardiovascular mortality (time to event), we applied the baseline Cox proportional hazards model. No participants in our data were lost or withdrew, so censoring only occurs when the participants lived until the study end (31 December 2012) or when the participants died from causes other than the outcomes of interest. The cause-specific relative hazard and the subdistribution relative hazard approaches were used in competing risks analysis. ${ }^{24}$ The results from competing risk analysis were used as the sensitivity analysis. Since the data show the dates of death in year-month format, we input the middle day of the month as the date of death. For those participants who died in the same month as the date of the health check-up visit, we input the last day of the month as the date of death..$^{25}$ The analysis was conducted separately by gender.

\section{RESULTS}

Among the included participants' visits (table 1), the number of males (853) with cardiovascular deaths exceeded that of females (411). In the younger elderly participants (age 65-74), the females $(22,675)$ outnumbered males $(18,258)$. Among included participants, a much higher proportion of females were in this younger elderly group $(72.68 \%)$, whereas males showed the opposite pattern. In the underweight $(<18.5)$, the females had proportions $(3.96 \%)$ similar to that of the males $(3.90 \%)$. The proportion of males $(33.86 \%)$ was larger than females $(29.82 \%)$ in the overweight $(24 \leq \mathrm{BMI}<27)$ group; on the other hand, the proportions of slightly obese $(27 \leq \mathrm{BMI}<30)$, moderately obese $(30 \leq \mathrm{BMI}<35)$ and severely obese $(\mathrm{BMI} \geq 35)$ were much higher in females $(13.90 \%, 5.33 \%, 0.66 \%)$ than in males $(12.54 \%, 3.52 \%$, $0.27 \%)$. The proportions having heart diseases $(25.80 \%)$ and diabetes history $(27.79 \%)$ were slightly higher in males. The proportion having hypertension history in females $(74.90 \%)$ was almost the same as in males (74.62\%). The proportions of non-smoking $(96.92 \%)$ and non-drinking $(90.51 \%)$ behaviours were much higher in females. In normal eGFR (eGFR $\geq 90$ ) and slightly mildly decreased eGFR groups $(90>\mathrm{eGFR} \geq 60)$, the proportion of females was higher $(4.77 \%, 57.51 \%)$ than males $(1.67 \%, 45.53 \%)$. However, in the mildly decreased eGFR group $(60>\mathrm{eGFR} \geq 45)$ and moderately decreased eGFR group (eGFR <45), the proportion of males was higher $(41.40 \%, 11.40 \%)$ than females $(29.42 \%, 8.30 \%)$. The females with eGFR decline $(\leq-5)$ had a slightly higher proportion $(14.30 \%)$ than the males $(12.20 \%)$. Last, a much higher proportion of females were in the normal urine protein group (-) $(86.78 \%)$, whereas males showed the opposite pattern.

The results of the adjusted Cox proportional hazards model are shown in table 2. Compared with the persons with eGFR $>90 \mathrm{~mL} / \mathrm{min} / 1.73 \mathrm{~m}^{2}$, a significant higher risk of cardiovascular death was observed with eGFR 45-59 (male: HR: 2.85, 95\% CI: 1.33 to 6.09; female: HR: 3.66, $95 \%$ CI: 1.32 to 10.15 ) and eGFR $<45 \mathrm{~mL} / \mathrm{min} / 1.73 \mathrm{~m}^{2}$ 
Table 1 Characteristics of included participants' visits stratified by gender

\begin{tabular}{|c|c|c|c|}
\hline Variables & $\begin{array}{l}\text { Male (n: } 33532) \\
\text { Mean } \pm \text { SD/counts (\%) }\end{array}$ & $\begin{array}{l}\text { Female (n: } 31200) \\
\text { Mean } \pm \text { SD/counts (\%) }\end{array}$ & $P$ value \\
\hline CVD deaths & $853(2.54)$ & $411(1.32)$ & $<0.001$ \\
\hline \multicolumn{4}{|l|}{ Age } \\
\hline $65-74$ & $18258(54.45)$ & $22675(72.68)$ & $<0.001$ \\
\hline$\geq 75$ & $15274(45.55)$ & 8525 (27.32) & \\
\hline \multicolumn{4}{|l|}{ BMI } \\
\hline $18.5 \leq \mathrm{BMl}<24$ (normal) & $15390(45.90)$ & $14452(46.32)$ & $<0.001$ \\
\hline $\mathrm{BMI}<18.5$ & $1308(3.90)$ & $1237(3.96)$ & \\
\hline $24 \leq \mathrm{BMI}<27$ & $11355(33.86)$ & $9305(29.82)$ & \\
\hline $27 \leq \mathrm{BMl}<30$ & $4205(12.54)$ & $4336(13.90)$ & \\
\hline $30 \leq \mathrm{BMl}<35$ & $1182(3.52)$ & $1664(5.33)$ & \\
\hline $\mathrm{BMI} \geq 35$ & $92(0.27)$ & $206(0.66)$ & \\
\hline Heart disease history & $8651(25.80)$ & $7462(23.92)$ & $<0.001$ \\
\hline Hypertension history & $25023(74.62)$ & $23369(74.90)$ & 0.424 \\
\hline Diabetes mellitus history & $9317(27.79)$ & $8390(26.89)$ & 0.011 \\
\hline \multicolumn{4}{|l|}{ Smoking status } \\
\hline Non-smoking & $29447(87.82)$ & 30238 (96.92) & $<0.001$ \\
\hline Smoking occasionally & $2250(6.71)$ & $585(1.87)$ & \\
\hline Smoking every day & $1835(5.47)$ & $377(1.21)$ & \\
\hline \multicolumn{4}{|l|}{ Drinking status } \\
\hline Non-drinking & $24569(73.27)$ & $28240(90.51)$ & $<0.001$ \\
\hline Drinking & $8963(26.73)$ & $2960(9.49)$ & \\
\hline Creatine $(\mathrm{mg} / \mathrm{dL})$ & $1.14 \pm 0.47$ & $0.88 \pm 0.47$ & $<0.001$ \\
\hline \multicolumn{4}{|l|}{ eGFR category } \\
\hline eGFR $\geq 90$ & $561(1.67)$ & $1487(4.77)$ & $<0.001$ \\
\hline $90>$ eGFR $\geq 60$ & $15266(45.53)$ & $17943(57.51)$ & \\
\hline $60>\mathrm{eGFR} \geq 45$ & $13882(41.40)$ & $9180(29.42)$ & \\
\hline eGFR $<45$ & $3823(11.40)$ & $2590(8.30)$ & \\
\hline \multicolumn{4}{|l|}{ eGFR decline } \\
\hline Slope $>-5$ & $29441(87.80)$ & 26739 (85.70) & $<0.001$ \\
\hline Slope $\leq-5$ & $4091(12.20)$ & $4461(14.30)$ & \\
\hline \multicolumn{4}{|l|}{ Urine protein } \\
\hline- & $27513(82.05)$ & $27074(86.78)$ & $<0.001$ \\
\hline$+/-,+,++$ & $5681(16.94)$ & $3962(12.70)$ & \\
\hline,+++++++ & $338(1.01)$ & $164(0.53)$ & \\
\hline No of visits & $4.35 \pm 2.02$ & $4.11 \pm 1.93$ & $<0.001$ \\
\hline Duration of follow-up (years) & $4.22 \pm 2.13$ & $4.04 \pm 2.10$ & $<0.001$ \\
\hline
\end{tabular}

Continuous variables are presented as mean \pm SD; category variables are expressed as a count (\%).

$\mathrm{BMI}$, body mass index; CVD, cardiovascular disease; eGFR, estimated glomerular filtration rate.

(male: HR: $3.98,95 \%$ CI: 1.84 to 8.61 ; female: HR: 6.77 , 95\% CI: 2.41 to 18.99 ). The eGFR decline slope $\leq-5$ (male: HR: 3.24, 95\% CI: 2.73 to 3.85; female: HR: 2.83, $95 \%$ CI: 2.20 to 3.64$)$, urine protein $(+/-,+,++$, male: HR: $1.51,95 \%$ CI: 1.29 to 1.78 ; female: HR: $1.93,95 \%$ CI: 1.54 to 2.42$)$, and urine protein (+++, ++++ , male: HR: 2.31, $95 \%$ CI: 1.51 to 3.53; female: HR: $4.23,95 \%$ CI: 2.34 to 7.65) were associated with an increased risk of cardiovascular death. Additionally, age $\geq 75$ years and having heart disease history were independent risk factors for cardiovascular death in both genders. The association between a history of hypertension and the risk of cardiovascular death was only significant in males. Furthermore, competing risk analysis determined that eGFR $<90 \mathrm{~mL} /$ 
Table 2 The estimated risks of cardiovascular deaths from explanatory variables by gender

\begin{tabular}{|c|c|c|c|c|c|c|}
\hline \multirow[b]{3}{*}{ Variables } & \multicolumn{3}{|l|}{ Male } & \multicolumn{3}{|c|}{ Female } \\
\hline & \multirow[b]{2}{*}{ HR } & \multicolumn{2}{|c|}{$95 \% \mathrm{Cl}$} & \multirow[b]{2}{*}{ HR } & \multicolumn{2}{|c|}{$95 \% \mathrm{Cl}$} \\
\hline & & LCI & UCI & & LCI & $\mathrm{UCI}$ \\
\hline Age $\geq 75$ & 2.93 & 2.48 & 3.46 & 4.95 & 3.91 & 6.26 \\
\hline \multicolumn{7}{|l|}{$\mathrm{BMI}(18.5 \leq \mathrm{BMl}<24$ as a reference) } \\
\hline $24 \leq \mathrm{BMl}<27$ & 0.84 & 0.72 & 0.98 & 0.87 & 0.69 & 1.10 \\
\hline $27 \leq \mathrm{BMl}<30$ & 0.90 & 0.72 & 1.12 & 0.89 & 0.65 & 1.20 \\
\hline $30 \leq \mathrm{BMl}<35$ & 0.93 & 0.64 & 1.36 & 1.17 & 0.79 & 1.74 \\
\hline $\mathrm{BMI} \geq 35$ & 1.40 & 0.51 & 3.83 & 1.19 & 0.44 & 3.26 \\
\hline Having heart disease history & 1.45 & 1.26 & 1.67 & 1.57 & 1.28 & 1.93 \\
\hline \multicolumn{7}{|c|}{ Smoking status (non-smoking as a reference) } \\
\hline Smoking occasionally & 0.87 & 0.62 & 1.21 & 0.76 & 0.31 & 1.87 \\
\hline Smoking every day & 1.04 & 0.79 & 1.35 & 0.94 & 0.42 & 2.11 \\
\hline \multicolumn{7}{|c|}{ Drinking status (non-drinking as a reference) } \\
\hline Drinking & 0.95 & 0.81 & 1.11 & 0.78 & 0.53 & 1.13 \\
\hline \multicolumn{7}{|c|}{ Renal function (eGFR $\geq 90$ as a reference) } \\
\hline $90>\mathrm{eGFR} \geq 60$ & 1.91 & 0.90 & 4.06 & 2.43 & 0.89 & 6.64 \\
\hline $60>\mathrm{eGFR} \geq 45$ & 2.85 & 1.33 & 6.09 & 3.66 & 1.32 & 10.15 \\
\hline eGFR $<45$ & 3.98 & 1.84 & 8.61 & 6.77 & 2.41 & 18.99 \\
\hline
\end{tabular}

BMI, body mass index; eGFR, estimated glomerular filtration rate; LCl, lower 95\% confidence interval; UCl, upper 95\% confidence interval.

$\min / 1.73 \mathrm{~m}^{2}$, positive proteinuria and rapid decline in eGFR were associated with an increased risk of cardiovascular mortality (online supplemental tables S1 and S2).

We stratified our participants into 12 groups based on different levels of renal function (eGFR $\geq 90$, $90>\mathrm{eGFR} \geq 60,60>\mathrm{eGFR} \geq 45$, eGFR $<45)$ and different levels of urine protein $((-),(+/-,+,++)$, and $(+++$ or $++++)$ ). Table 3 shows the joint effect of eGFR and urine protein with cardiovascular mortality different between genders. Compared with participants with normal renal function (eGFR $\geq 90+$ urine protein $(-)$ ), those who met eGFR $<60 \mathrm{~mL} / \mathrm{min} / 1.73 \mathrm{~m}^{2}$ or tested positive in urine protein had a significant increase in cardiovascular mortality. When participants met both criteria, eGFR $<60 \mathrm{~mL} / \mathrm{min} / 1.73 \mathrm{~m}^{2}$ and having proteinuria, the risk of cardiovascular mortality in males and females was significantly increased by more than three and six times, respectively.
Figure 2A-C shows that the survival curves estimated by the Cox proportional hazards model depends on different levels of renal function and different levels of urine protein. The worse urine protein and worse reduction in eGFR a participant had, the lower their probability of survival. Additionally, the survival probabilities among females were higher than those among males in all groups.

\section{DISCUSSION}

In this cohort study, we observed significant and independent associations of a lower eGFR level, an elevated level of protein in urine, and a rapid past decline in eGFR with with higher risk of cardiovascular mortality. The joint effect of increased concentration of urine protein and reduced eGFR was associated with a lower survival probability. 
Table 3 The joint effect of eGFR and urine protein with cardiovascular mortality

\begin{tabular}{|c|c|c|c|c|}
\hline \multirow[b]{3}{*}{ Variables } & \multicolumn{4}{|c|}{ Cardiovascular mortality } \\
\hline & \multicolumn{2}{|l|}{ Male } & \multicolumn{2}{|l|}{ Female } \\
\hline & HR $(95 \% \mathrm{Cl})$ & $P$ value & HR $(95 \% \mathrm{Cl})$ & $P$ value \\
\hline eGFR $\geq 90+$ urine protein $(-)$ & Ref & - & Ref & - \\
\hline $90>$ eGFR $\geq 60+$ urine protein $(-)$ & $1.93(0.79$ to 4.71$)$ & 0.148 & 2.84 (0.90 to 9.00$)$ & 0.076 \\
\hline $60>$ eGFR $\geq 45+$ urine protein $(-)$ & 2.92 (1.19 to 7.15$)$ & 0.019 & 4.14 (1.29 to 13.3$)$ & 0.017 \\
\hline eGFR $<45+$ urine protein $(-)$ & 3.80 (1.53 to 9.46$)$ & 0.004 & $6.88(2.10$ to 22.5$)$ & 0.001 \\
\hline eGFR $\geq 90+$ urine protein $(+/-,+,++)$ & 1.57 (0.30 to 8.08$)$ & 0.591 & $3.27(0.34$ to 31.5$)$ & 0.305 \\
\hline $90>$ eGFR $\geq 60+$ urine protein $(+/-,+,++)$ & 2.85 (1.14 to 7.10$)$ & 0.025 & $4.72(1.44$ to 15.5$)$ & 0.011 \\
\hline $60>$ eGFR $\geq 45+$ urine protein $(+/-,+,++)$ & 4.18 (1.68 to 10.4$)$ & 0.002 & 7.72 (2.36 to 25.2$)$ & $<0.001$ \\
\hline eGFR $<45+$ urine protein $(+/-,+,++)$ & $6.70(2.65$ to 17.0$)$ & $<0.001$ & 16.8 (5.04 to 56.1$)$ & $<0.001$ \\
\hline eGFR $\geq 90+$ urine protein $(+++,++++)^{*}$ & - & - & - & - \\
\hline $90>$ eGFR $\geq 60+$ urine protein $(+++,++++)$ & 5.02 (1.53 to 16.5$)$ & 0.008 & $7.43(1.49$ to 37.0$)$ & 0.014 \\
\hline $60>$ eGFR $\geq 45+$ urine protein $(+++,++++)$ & 5.71 (1.94 to 16.8$)$ & 0.002 & $17.0(4.03$ to 71.8$)$ & $<0.001$ \\
\hline eGFR $<45+$ urine protein $(+++,++++)$ & 10.6 (3.43 to 32.68$)$ & $<0.001$ & $55.9(12.3$ to 254$)$ & $<0.001$ \\
\hline
\end{tabular}

Adjusted for age, BMI, heart disease history, hypertension history, diabetes mellitus history, smoking, drinking and eGFR decline. ${ }^{*}$ Only three men were in this state, and they were merged into the group of eGFR $\geq 90+$ urine protein $(+/-,+,++)$ for analysis. eGFR, estimated glomerular filtration rate.

Decreased GFR and persistent proteinuria are markers of kidney damage, and are associated with an increased risk of cardiovascular mortality. ${ }^{9} 1213$ Our findings indicate that testing positive for proteinuria is an independent risk factor for cardiovascular mortality in our participants, and this is more evident in females than in males. The results of this study are consistent with previous studies, although the latter were not conducted in Asian populations. ${ }^{26}{ }^{27}$ The eGFR $<60 \mathrm{~mL} / \mathrm{min} / 1.73 \mathrm{~m}^{2}$ is an independent risk factor for cardiovascular mortality in our participants, and was more prominent in females than in males. However, the results are different from other studies. Zambon et al found that all participants (Italian population aged 65 years and older) with eGFR $<60 \mathrm{~mL} / \mathrm{min} / 1.73 \mathrm{~m}^{2}$ had an increased risk of cardiovascular mortality, although this was not significant in men (HR 2.13, 95\% CI 0.84 to 5.42) and women (HR $1.73,95 \%$ CI 0.92 to 3.27 ) separately. ${ }^{27}$ A longitudinal study showed the eGFR $<45 \mathrm{~mL} / \mathrm{min} / 1.73 \mathrm{~m}^{2}$ is an independent risk factor for cardiovascular mortality in the communitybased elderly population (65-75 years old) in Japan, and analysis by gender showed that the HR of cardiovascular mortality is more evident in males (HR 3.14, 95\% CI 1.50 to 6.94 ) than in females (HR $1.48,95 \%$ CI 0.41 to 4.19$){ }^{28}$ However, they did not include eGFR slope in their analysis. It is speculated that the difference in results is partially affected by the magnitude of eGFR decline between men and women. In addition, obesity not only is a risk factor for CKD but is also associated with increased risk of cardiovascular events and cardiovascular mortality, which may involve adipose tissue promoting several metabolic disorders and cardiac structure change caused by haemodynamic alterations. ${ }^{29-31}$ Females have a higher proportion of obesity than males in this study population (table 1), which may result in the risk of cardiovascular mortality being more significant in females than in males. In addition, the joint effect of impaired eGFR and proteinuria on high risk of cardiovascular mortality has been reported in the elderly, ${ }^{27}$ but the difference in sex has not been analysed yet.

Urinary protein excretion not only reflects localised subclinical renal disease but also a more generalised vascular endothelial dysfunction. ${ }^{32}$ Proteinuria is linked to higher high-sensitivity troponin $\mathrm{T}$, a vascular micronecrosis marker, ${ }^{33}$ and $\mathrm{C}$ reactive protein, an inflammation marker. ${ }^{34}$ These results indicate that proteinuria is related to endothelial dysfunction. Oestrogen has vasodilatory effects and longterm actions that inhibit the response to vascular injury and prevent atherosclerosis. ${ }^{35}$ In an elderly population, without oestrogen protection, females with proteinuria may have higher risk of cardiovascular mortality than males.

As far as we know, only a study by Nerpin et al has shown that the combination of urinary albumin excretion rate and cystatin C-based eGFR is beneficial to improve the prediction of cardiovascular mortality in elderly men. ${ }^{36}$ In our study, the effect of a combination of increased urine protein concentration and reduced eGFR was associated with a lower survival probability. Participants with both eGFR $<60 \mathrm{~mL} /$ $\min / 1.73 \mathrm{~m}^{2}$ and positive urine protein showed a higher risk of cardiovascular mortality compared with participants with normal renal function, and this was more prominent in females than in males.

Rapid decline in renal function is a risk factor for cardiovascular mortality. Rifkin et alfound an association between the change of eGFR $>3 \mathrm{~mL} / \mathrm{min} / 1.73 \mathrm{~m}^{2} /$ yearand elevated risk for all-cause and cardiovascular mortality in older adults. ${ }^{22}$ Sumida et al also showed that rapid decline of eGFR (slopes of $<-5 \mathrm{~mL} / \mathrm{min} / 1.73 \mathrm{~m}^{2} /$ year) is associated with higher 


\section{A. Protein in urine is negative}
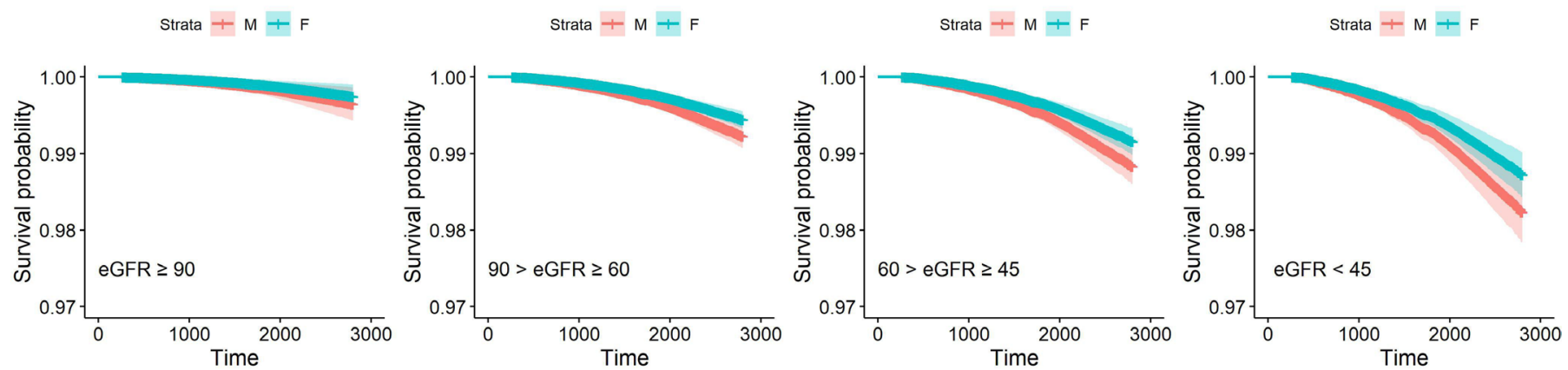

\section{B. Protein in urine is $+/-,+$, or ++}
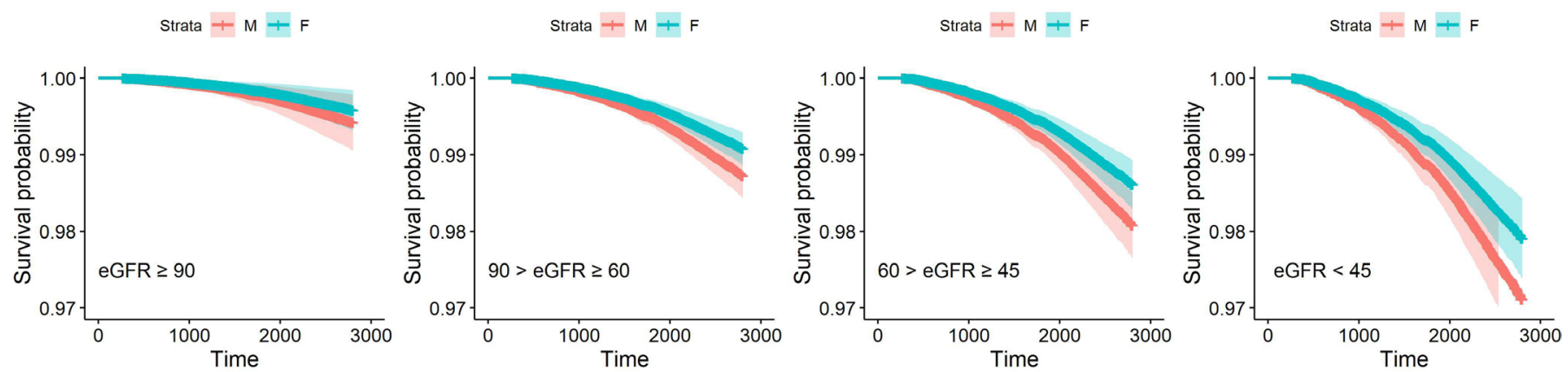

C. Protein in urine is +++ or ++++
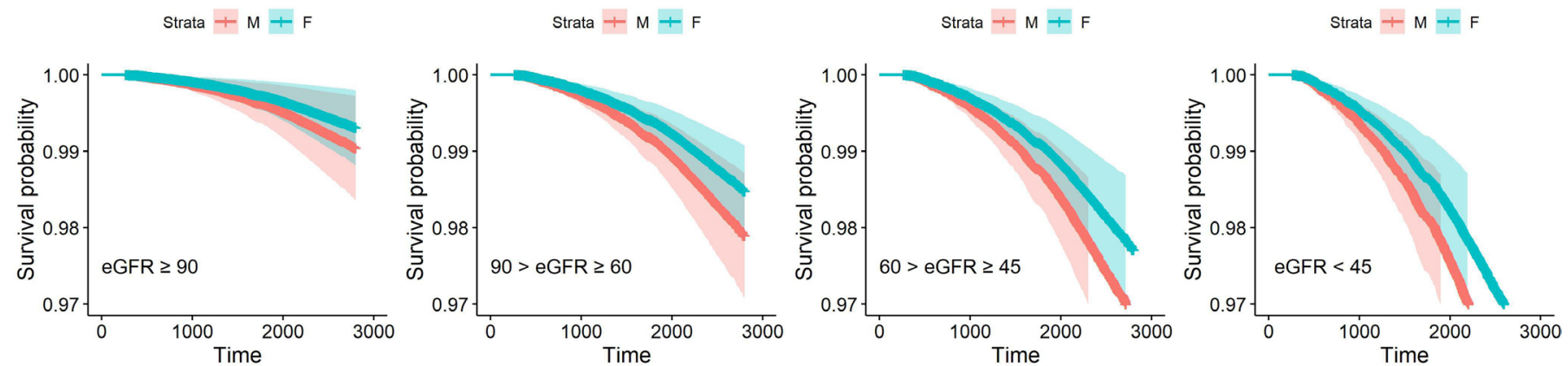

Figure 2 Plots of survival curves which applied Cox proportional hazards model to estimate males' and females' survival depends on different levels of renal function and different levels of urine protein. (A) It shows the survival probability under different levels of renal function when the protein in urine is negative. (B) It shows the survival probability under different levels of renal function when the protein in urine is $+/-,+$ or ++ . (C) It shows the survival probability under different levels of renal function when the protein in urine is +++ or ++++ . eGFR, estimated glomerular filtration rate.

all-cause and cardiovascular mortality in advanced CKD of veterans in the USA. ${ }^{37}$ To the best of our knowledge, no study provides results on gender effects, but it has been proposed that males have poor prognosis of kidney diseases. ${ }^{38-40}$ Our results suggest that the risk of cardiovascular mortality in elderly men and women who had rapid decline in renal function (eGFR decline $<-5 \mathrm{~mL} / \mathrm{min} / 1.73 \mathrm{~m}^{2} /$ year) was, respectively, 2.24 and 1.83 times more than their counterparts.

The advantage of our study is that this is a cohort study of elderly persons in Taipei, a major city in Taiwan, which is a large and representative population. In addition, there have been only limited studies discussing cardiovascular mortality's relationship to both renal function and the magnitude of renal function decline in elderly Asians; we contribute to filling this gap and also analysed the effect of gender. However, the limitations of our study should be noted. First, our results cannot extrapolate to the entire Asian elderly population, but the results can still be used as a reference for the generalised elderly population. Second, we were unable to obtain a better proteinuria index-ACR. ACR is calculated by dividing the concentration of urine albumin by the concentration of urine creatinine to eliminate the dilution or concentration effect caused by hydration, which is a more objective evaluation of the amount of albumin in urine. ${ }^{41}$ The proteinuria test in the database used a (semiquantitative) urine test strip to estimate the amount of proteinuria by valence $(-,+/-,+, 2+, 3+$ and $4+)$, which is not as accurate as the (quantitative) microalbumin test, and there were no data available on urine creatinine to calculate ACR. 
However, the urine test strip is the most common tool for preliminary screening of proteinuria. Our findings could provide an early warning to identify groups with a high risk of cardiovascular mortality.

\section{CONCLUSIONS}

With routine and simple indicators from health examinations, renal function and urine protein can be a sensitive indicator for reducing the mortality risk of the elderly.

\section{Author affiliations}

${ }^{1}$ Research Center for Humanities and Social Sciences, Academia Sinica, Taipei, Taiwan

${ }^{2}$ Institute of Public Health, School of Medicine, National Yang Ming Chiao Tung University, Taipei, Taiwan

${ }^{3}$ Division of Nephrology, Department of Internal Medicine, Kaohsiung Medical University Hospital, Kaohsiung Medical University, Kaohsiung, Taiwan

${ }^{4}$ Department of Internal Medicine, Kaohsiung Municipal Ta-Tung Hospital,

Kaohsiung, Taiwan

${ }^{5}$ Department of Medicine, College of Medicine, Kaohsiung Medical University, Kaohsiung, Taiwan

${ }^{6}$ Division of Infectious Disease, Department of Internal Medicine, Kaohsiung Medical University Hospital, Kaohsiung Medical University, Kaohsiung, Taiwan

${ }^{7}$ School of Medicine, Graduate Institute of Medicine, Sepsis Research Center, Research Center of Tropical Medicine and Infectious Disease, Kaohsiung Medical University, Kaohsiung, Taiwan

${ }^{8}$ Institute of Medical Science and Technology, National Sun Yat-sen University, Kaohsiung, Taiwan

${ }^{9}$ Department of Biological Science and Technology, College of Biological Science and Technology, National Yang Ming Chiao Tung University, Hsinchu, Taiwan

Acknowledgements We gratefully thank the Department of Health, Taipei City Government for allowing use of their data for this study. We thank Mr Yi-Chi Chu for analysing the competing risk model in the revision.

Contributors Y-JH, Y-LH and T-CC conceptualised and designed the paper, interpreted the results and drafted the manuscript. Y-JH, Y-LH and TCC reviewed the literature and made substantial contributions to the conception and design. Y-LH and Y-HC refined the data and performed statistical analysis. Y-LH and Y-HC contributed to the interpretation of the results. All authors read and approved the final manuscript.

Funding This research was supported by a grant from the Ministry of Science and Technology, Taiwan (MOST-106-2627-M-001-003) and a grant titled 'Multidisciplinary Health Cloud Research Programme: Technology Development and Application of Big Health Data' from Academia Sinica.

Competing interests None declared.

Patient consent for publication Not applicable.

Ethics approval This study was approved by the Institutional Review Board (IRB) on Biomedical Science Research, Academia Sinica (AS-IRB02-104182). This study was designed as a retrospective longitudinal cohort study. Every enrolled participant needed to fill out an informed consent form to authorise the Taipei City Government to process health examination data for the research purpose.

Provenance and peer review Not commissioned; externally peer reviewed.

Data availability statement Data may be obtained from a third party and are not publicly available. The raw data are confidential and cannot readily be shared. Researchers need to obtain permission from the Institutional Review Board and apply for access to the data from the Department of Health, Taipei City Government.

Supplemental material This content has been supplied by the author(s). It has not been vetted by BMJ Publishing Group Limited (BMJ) and may not have been peer-reviewed. Any opinions or recommendations discussed are solely those of the author(s) and are not endorsed by BMJ. BMJ disclaims all liability and responsibility arising from any reliance placed on the content. Where the content includes any translated material, BMJ does not warrant the accuracy and reliability of the translations (including but not limited to local regulations, clinical guidelines, terminology, drug names and drug dosages), and is not responsible for any error and/or omissions arising from translation and adaptation or otherwise.

Open access This is an open access article distributed in accordance with the Creative Commons Attribution Non Commercial (CC BY-NC 4.0) license, which permits others to distribute, remix, adapt, build upon this work non-commercially, and license their derivative works on different terms, provided the original work is properly cited, appropriate credit is given, any changes made indicated, and the use is non-commercial. See: http://creativecommons.org/licenses/by-nc/4.0/.

\section{ORCID iDs}

Yung-Hsin Chuang http://orcid.org/0000-0002-0948-5660

Ta-Chien Chan http://orcid.org/0000-0002-1685-783X

\section{REFERENCES}

1 Chen TK, Knicely DH, Grams ME. Chronic kidney disease diagnosis and management: a review. JAMA 2019;322:1294-304.

2 Iseki $\mathrm{K}$, disease Ckidney. (CKD) as an emerging risk factor in the elderly. In: Washio M, Kiyohara C, eds. Health issues and care system for the elderly. Singapore: Springer Singapore, 2019: 137-50.

3 Mallappallil M, Friedman EA, Delano BG, et al. Chronic kidney disease in the elderly: evaluation and management. Clin Pract 2014:11:525-35.

4 So S, Stevenson J, Lee V. Kidney diseases in the elderly. advanced age geriatric care. Springer, 2019: 131-44.

5 Liu BC, Tang TT, LL L. How tubular epithelial cell injury contributes to renal fibrosis. In: Liu BC, Lan HY, LL L, eds. Renal fibrosis: mechanisms and therapies. Singapore: Springer Singapore, 2019: 233-52.

6 Chou Y-H, Huang T-M, Chu T-S. Novel insights into acute kidney injury-chronic kidney disease continuum and the role of reninangiotensin system. J Formos Med Assoc 2017;116:652-9.

7 GBD 2017 Causes of Death Collaborators. Global, regional, and national age-sex-specific mortality for 282 causes of death in 195 countries and territories, 1980-2017: a systematic analysis for the global burden of disease study 2017. Lancet 2018;392:1736-88.

8 GBD Chronic Kidney Disease Collaboration. Global, regional, and national burden of chronic kidney disease, 1990-2017: a systematic analysis for the global burden of disease study 2017. Lancet 2020;395:709-33.

9 Chronic Kidney Disease Prognosis Consortium, Matsushita K, van der Velde M, et al. Association of estimated glomerular filtration rate and albuminuria with all-cause and cardiovascular mortality in general population cohorts: a collaborative meta-analysis. Lancet 2010;375:2073-81.

10 Matsushita K, Coresh J, Sang Y, et al. Estimated glomerular filtration rate and albuminuria for prediction of cardiovascular outcomes: a collaborative meta-analysis of individual participant data. Lancet Diabetes Endocrinol 2015;3:514-25.

11 Gansevoort RT, Correa-Rotter R, Hemmelgarn BR, et al. Chronic kidney disease and cardiovascular risk: epidemiology, mechanisms, and prevention. Lancet 2013;382:339-52.

12 Hallan S, Astor B, Romundstad S, et al. Association of kidney function and albuminuria with cardiovascular mortality in older vs younger individuals: the HUNT II study. Arch Intern Med 2007;167:2490-6.

13 Irie $\mathrm{F}$, Iso $\mathrm{H}$, Sairenchi $\mathrm{T}$, et al. The relationships of proteinuria, serum creatinine, glomerular filtration rate with cardiovascular disease mortality in Japanese general population. Kidney Int 2006;69:1264-71.

14 van der Velde M, Matsushita K, Coresh J, et al. Lower estimated glomerular filtration rate and higher albuminuria are associated with all-cause and cardiovascular mortality. A collaborative meta-analysis of high-risk population cohorts. Kidney Int 2011;79:1341-52.

15 Wang J, Wang F, Liu S, et al. Reduced kidney function, albuminuria, and risks for all-cause and cardiovascular mortality in China: a population-based cohort study. BMC Nephrol 2017;18:188.

16 Turin TC, Coresh J, Tonelli M, et al. Short-Term change in kidney function and risk of end-stage renal disease. Nephrol Dial Transplant 2012;27:3835-43.

17 Tsai C-W, Ting I-W, Yeh H-C, et al. Longitudinal change in estimated GFR among CKD patients: a 10-year follow-up study of an integrated kidney disease care program in Taiwan. PLOS One 2017;12:e0173843

18 Grams ME, Sang Y, Ballew SH, et al. Evaluating glomerular filtration rate slope as a surrogate end point for ESKD in clinical trials: an individual participant meta-analysis of observational data. J Am Soc Nephrol 2019;30:1746-55. 
19 Turin TC, Jun M, James MT, et al. Magnitude of rate of change in kidney function and future risk of cardiovascular events. Int $\mathrm{J}$ Cardiol 2016;202:657-65.

20 Shlipak MG, Katz R, Kestenbaum B, et al. Rapid decline of kidney function increases cardiovascular risk in the elderly. J Am Soc Nephrol 2009;20:2625-30.

21 Sumida K, Molnar MZ, Potukuchi PK, eds. Association of slopes of estimated GFR with post-ESRD mortality in advanced CKD patients transitioning to dialysis. Mayo Clin Proc. NIH Public Access, 2016.

22 Rifkin DE, Shlipak MG, Katz R, et al. Rapid kidney function decline and mortality risk in older adults. Arch Intern Med 2008;168:2212-8.

23 Schaeffner ES, Ebert N, Delanaye P, et al. Two novel equations to estimate kidney function in persons aged 70 years or older. Ann Intern Med 2012;157:471-81.

24 Lau B, Cole SR, Gange SJ. Competing risk regression models for epidemiologic data. Am J Epidemiol 2009;170:244-56.

25 Woods LM, Rachet B, Ellis L, et al. Full dates (day, month, year) should be used in population-based cancer survival studies. Int $J$ Cancer 2012;131:E1120-4.

26 Culleton BF, Larson MG, Parfrey PS, et al. Proteinuria as a risk factor for cardiovascular disease and mortality in older people: a prospective study. Am J Med 2000;109:1-8.

27 Zambon S, Maggi S, Zanoni S, et al. Association of single measurement of estimated glomerular filtration rate and nonquantitative dipstick proteinuria with all-cause and cardiovascular mortality in the elderly. results from the Progetto Veneto Anziani (Pro.V.A.) study. Atherosclerosis 2012;220:201-7.

28 Kon S, Konta T, Ichikawa K, et al. Association between renal function and cardiovascular and all-cause mortality in the community-based elderly population: results from the specific health check and guidance program in Japan. Clin Exp Nephrol 2018;22:346-52.

29 Wahba IM, Mak RH. Obesity and obesity-initiated metabolic syndrome: mechanistic links to chronic kidney disease. Clin J Am Soc Nephrol 2007;2:550-62.

30 Gertow J, Ng CZ, Mamede Branca RM, et al. Altered protein composition of subcutaneous adipose tissue in chronic kidney disease. Kidney Int Rep 2017;2:1208-18.
31 Liu C, Li G, Laukkanen JA, et al. Overweight and obesity are associated with cardiac adverse structure remodeling in Chinese elderly with hypertension. Sci Rep 2019;9:1-7.

32 Deckert T, Feldt-Rasmussen B, Borch-Johnsen K, et al. Albuminuria reflects widespread vascular damage. The Steno hypothesis. Diabetologia 1989;32:219-26.

33 Hellemons ME, Lambers Heerspink HJ, Gansevoort RT, et al. High-Sensitivity troponin T predicts worsening of albuminuria in hypertension; results of a nested case-control study with confirmation in diabetes. J Hypertens 2013;31:805-12.

34 Tsioufis C, Dimitriadis K, Chatzis D, et al. Relation of microalbuminuria to adiponectin and augmented C-reactive protein levels in men with essential hypertension. Am J Cardiol 2005;96:946-51.

35 lorga A, Cunningham CM, Moazeni S, et al. The protective role of estrogen and estrogen receptors in cardiovascular disease and the controversial use of estrogen therapy. Biol Sex Differ 2017;8:1-16.

36 Nerpin E, Ingelsson E, Risérus U, et al. The combined contribution of albuminuria and glomerular filtration rate to the prediction of cardiovascular mortality in elderly men. Nephrol Dial Transplant 2011;26:2820-7.

37 Sumida K, Molnar MZ, Potukuchi PK, eds. Association of slopes of estimated glomerular filtration rate with post-end-stage renal disease mortality in patients with advanced chronic kidney disease transitioning to dialysis. Mayo Clin Proc. Elsevier, 2016.

38 Neugarten J, Acharya A, Silbiger SR. Effect of gender on the progression of nondiabetic renal disease: a meta-analysis. J Am Soc Nephrol 2000;11:319-29.

39 Minutolo R, Gabbai FB, Chiodini P, et al. Sex differences in the progression of CKD among older patients: pooled analysis of 4 cohort studies. Am J Kidney Dis 2020;75:30-8.

40 Eriksen BO, Ingebretsen OC. The progression of chronic kidney disease: a 10-year population-based study of the effects of gender and age. Kidney Int 2006;69:375-82.

41 Levey AS, Coresh J, Balk E, et al. National kidney Foundation practice guidelines for chronic kidney disease: evaluation, classification, and stratification. Ann Intern Med 2003;139:137-47. 